\title{
Analisis Faktor Penghambat Penyusunan SPJ Pengeluaran Di Dinas Penanaman Modal dan Pelayanan Terpadu Satu Pintu (DPMPTSP) Kota Magelang
}

\author{
Silvia Melina Wati \\ Universitas Tidar Magelang \\ silviamelina51@gmail.com
}

\section{Agustina Prativi Nugraheni \\ Universitas Tidar Magelang \\ devi.agustina@untidar.co.id}

\begin{abstract}
Abstrak Belanja Satuan Kerja Perangkat Daerah (SKPD) tentunya sangat berkaitan dengan setiap lembaga pemerintah. Belanja SKPD merupakan pengeluaran dana yang digunakan untuk membiayai kegiatan operasional kantor, dimana setiap pengeluaran atau belanja harus dilengkapi bukti yang lengkap dan sah yang akan digunakan untuk proses penyusunan SPJ Pengeluaran. Oleh karena itu, peneliti tertarik melakukan penelitian yang bertujuan untuk mengetahui dan menganalisis faktor penghambat penyusunan SPJ Pengeluaran. Penelitian ini menggunakan metode deskriptif kualitatif. Sumber data yang digunakan adalah data primer yang diperoleh langsung dari Dinas Penanaman Modal dan Pelayanan Terpadu Satu Pintu Kota Magelang. Hasil penelitian menunjukkan bahwa DPMPTSP Kota Magelang sudah menyusun SPJ dengan baik dan tepat waktu tetapi masih terdapat beberapa factor yang menghambat dalam penyusunan SPJ yaitu faktor pembagian kerja dimana setiap pegawai merangkap jabatan yang mengakibatkan kinerja pegawai tidak maksimal dan dokumen pelengkap SPJ yang banyak.
\end{abstract}

\section{Kata Kunci Belanja, Penyusunan SPJ Pengeluaran dan Faktor Penghambat}

Exstract
govenditure of Regional Working Unit (SKPD) are very related to every
finance office operational activities, where every expenditure must be
equipped with complete and valid evidence that will be used for the
process of preparing Accountability Letter (SPJ) Expenditure.
Therefore, the author is interested to do the research that aims to find
out and analyse the inhibiting factors for the preparation SPJ
Expenditure. This research used descriptive qualitative method. The
data source used in this study was primary data obtained directly from
the Board of Investment Services and One-stop Permit Services of
Magelang City. The results show that DPMPTSP of Magelang city has
conducted the preparation of SPJ properly and on time, but there are
still several inhibiting factors in the preparation of SPJ, namely the
division of labor which each employee has concurrent position that


results in employee performance not optimal and too many SPJ supplementary documents.

Keywords Expenditure, Preparation of SPJ Expenditure and Inhibiting Factor

\section{PENDAhUluAN}

Salah satu bidang akuntansi sektor publik adalah akuntansi keuangan daerah, yang mendapat perhatian besar dari berbagai pihak sejak tahun 1999-an. Hal tersebut disebabkan karena terjadi sistem pengelolaan yang buruk pada masa orde baru, sehingga Pemerintah Republik Indonesia mulai menerapkan kebijakan baru baru yang mereformasi pengelolaan keuangan darah. Tujuan diimplementasikannya kebijakan tersebut adalah untuk mewujudkan pengelolaan keuangan daerah yang lebih baik.

Berdasarkan Peraturan Menteri Dalam Negeri Nomor 21 tahun 2011 tentang Perubahan Kedua atas Peraturan Menteri Dalam Negeri Nomor 13 tahun 2006 tentang Pedoman Pengelolaan Keuangan Daerah, maka terjadi beberapa perubahan dalam tata kelola keuangan daerah. Salah satu perubahan dalam tata kelola keuangan daerah adalah mulai diterapkannya Standar Akuntansi Pemerintah (SAP). Selain itu, perubahan dalam peraturan tersebut juga meliputi desentralisasi sistem akuntansi dan keuangan, dimana setiap Satuan Kerja Perangkat Daerah (SKPD) diberikan peran dan tanggung jawab lebih besar untuk mengelola keuangannya sendiri.

Penerapan peraturan tersebut, diharapkan agar sistem pengelolaan keuangan di sektor pemerintahan dapat dikelola dengan lebih transparan dan akuntabel, serta mengedepankan partisipasi aktif masyarakat guna mewujudkan kesejahteraan masyarakat pada umumnya (Halim, 2002).

Standar akuntansi pemerintahan yang diterapkan dalam pengelolaan keuangan daerah dapat dilihat dalam pelaporan pertanggungjawaban pelaksanaan Anggaran Belanja dan Pendapatan Daerah (APBD). Pertanggungjawaban pelaksanaan APBD berdasarkan Permendagri Nomor 13 tahun 2006 berupa laporan realisasi APBD, neraca daerah, laporan arus kas, dan catatan atas laporan keuangan sesuai SAP.

Maka setelah adanya perubahan, sesuai dengan Permendagri Nomor 21 tahun 2011 pertanggungjawaban pelaksanaan APBD dibuat dalam bentuk laporan keuangan yang terdiri dari Laporan Realisasi Anggaran (LRA), Laporan Operasional, Laporan Perubahan Saldo Anggaran Lebih, Laporan Perubahan Ekuitas, Neraca, Laporan Arus Kas (LAK), dan Catatan atas Laporan Keuangan (CaLK)

Sesuai dengan prinsip-prinsip pelaporan, yang salah satunya yaitu mengedepankan ketepatan waktu (timelines), maka Surat Pertanggungjawaban (SPJ) Pengeluaran harus disampaikan tepat waktu agar dapat menghasilkan laporan keuangan secara tepat waktu. Surat Pertanggungjawaban (SPJ) Pengeluaran merupakan dokumen yang menjelaskan penggunaan uang yang dikelola oleh bendahara pengeluaran dan dilengkapi dengan bukti-bukti transaksi yang berupa nota, kuitansi, dan bukti transaksi lainnya. Hal ini sesuai dengan prinsip penggunaan dana, dimana setiap pengeluaran atau belanja harus disertai bukti yang lengkap dan sah. Bendahara pengeluaran bertanggung jawab secara fungsional atas pengelolaan uang 
yang dikelola dan menyampaikan laporan pertanggungjawaban SKPD kepada PPKD selaku BUD paling lambat tanggal 10 setiap bulannya.

Terkait dengan pelaksanaan tugas penyusunan Surat Pertanggungjawaban (SPJ) Pengeluaran, DPMPTSP Kota Magelang masih mengalami hambatan dalam menyusun SPJ Pengeluaran tersebut. Oleh karena itu, tujuan penelitian ini adalah untuk mengetahui dan menganalisis faktor penghambat penyusunan Surat Pertanggungjawaban (SPJ) Pengeluaran pada Dinas Penanaman Modal dan Pelayanan Terpadu Satu Pintu (DPMPTSP) Kota Magelang

\section{LANDASAN TEORI}

\section{A. Pengertian Akuntansi Sektor Publik}

Akuntansi Sektor Publik adalah aktivitas akuntansi yang dilakukan terhadap kejadian dan transaksi keuangan organisasi sektor publik, (Siregar, 2015). Sektor publik meliputi badan-badan pemerintah (pemerintah pusat dan daerah serta unit-unit kerja pemerintah), perusahaan milik negara BUMN/BUMD, Yayasan, ormas, dan orpol, LSM, universitas, dan organisasi nirlaba lainnya.

Akuntansi sektor publik merupakan suatu alat informasi, karena laporan keuangan organisasi sektor publik memberikan informasi bagi pemerintah maupun masyarakat. (Mardiasmo, 2009) menyatakan akuntansi sektor publik terkait dengan tiga hal pokok, yaitu penyediaan informasi, pengendalian manajemen, dan akuntabilitas.

\section{B. Akuntansi Keuangan Daerah}

Akuntansi keuangan daerah merupakan salah satu bidang akuntansi akuntansi sektor publik. Akuntansi keuangan daerah adalah proses pengidentifikasian, pengukuran, pencatatan, dan pelaporan transaksi keuangan dari entitas pemerintah daerah dalam rangka pengembilan keputusan ekonomi yang diperlukan oleh pihak eksternal (Halim \& Kusufi, 2007).

Dalam Permendagri Nomor 13 tahun 2006 dinyatakan bahwa keuangan daerah adalah semua hak dan kewajiban daerah dalam rangka peyelenggaraan pemerintah daerah yang dapat dinilai dengan uang termasuk didalamnya segala bentuk kekayaan yang berhubungan dengan hak daan kewajiban daerah tersebut.

\section{Surat Pertanggungjawaban (SPJ)}

(LAN \& BPKP, 2000) mendefinisikan surat pertanggungjawaban (SPJ) sebagai salah satu bentuk laporan keuangan yang dihasilkan oleh bendahara juga telah memenuhi tujuan akuntabilitas. Hal tersebut karena SPJ dibuat untuk pertanggungjawaban atas penggunaan dana (APBD) kepada pihak yang lebih tinggi.

(Bastian, 2007) mendefinisikan SPJ adalah surat yang mempertanggungjawabkan pengeluaran-pengeluaran dan buku besar pembantu pengeluaran kas yang dilengkapi dengan bukti-bukti pengeluaran.

Dapat disimpulkan bahwa surat pertanggungjawaban pengeluaran merupakan surat yang mempertanggungjawabkan penggunaan dana atas kegiatan yang dilaksanakan oleh Lembaga atau institusi yang dilengkapi dengan bukti-bukti pengeluaran yang sah. 


\section{Pembagian Kerja}

Menurut (Hasibuan, 2007) pembagian kerja adalah informasi tertulis yang mennguraikan tugas dan tanggung jawab, kondisi pekerjaan, hubungan pekerjaan, dan aspek-aspek pekerjaan pada suatu jabatan tertentu dalam organisasi.

Dalam suatu organisasi, pembagian kerja sangat penting dilakukan. Hal tersebut dikarenakan dalam bidang ini semua pegawai memiliki tugas dan perannya masingmasing. Dengan demikian, adanya pembagian kerja akan membuat segala aktivitas yang ada didalam organisasi dibagi secara merata sesuai denga kemampuan setiap anggota organisasi.

\section{METODE PENELITIAN}

\section{A. Jenis Penelitian}

Penelitian ini merupakan penelitian yang melukiskan, menggambarkan, atau memaparkan keadaan obyek yang diteliti sesuai dengan situasi dan kondisi ketika penelitian tersebut dilakukan.

\section{B. Tempat dan Waktu Penelitian}

Lokasi penelitian ini adalah Dinas Penanaman Modal dan Pelayanan Terpadu Satu Pintu (DPMPTSP) Kota Magelang yang bertempat di Jalan Veteran Nomor 7 Kota Magelang. Waktu penelitan dilaksanakan pada bulan Januari-Februari 2020.

\section{Jenis Data}

Karakteristik objek data yang digunakan dalam penelitian ini adalah data kualitatif, yaitu jenis data penelitian yang berupa opini, sikap, pengalaman, atau karakteristik dari seseorang atau kelompok orang yang menjadi subyek penelitian (Indriantoro \& Supomo, 2002).

\section{Sumber Data}

Sumber data yang digunakan penulis dalam penyusunan adalah data primer, yang diperoleh dengan metode observasi dan wawancara yang dilakukan di Dinas Penanaman Modal dan Pelayanan Terpadu Satu Pintu (DPMPTSP) Kota Magelang. Data Primer adalah data asli yang dikumpulkan sendiri oleh penulis untuk menjawab penelitiannya secara khusus.

\section{E. Teknik Pengumpulan Data}

Untuk memperoleh data yang berkaitan dengan masalah yang diangkat, berikut ini adalah beberapa Teknik yang ditempuh oleh penulis yakni Studi Pustaka, Observasi, dan Wawancara.

\section{F. Metode Analisis}

Metode analisis yang digunakan dalam penelitian ini adalah analisis deskriptif yaitu metode yang dilakukan dengan cara mengumpulkan, menyajikan, serta 
menganalisis data agar dapat memberikan gambaran mengenai suatu keadaan tertentu, sehingga dapat ditarik kesimpulan.

\section{HASIL PENELITIAN}

\section{A. Sejarah Pembentukan Dinas Penanaman Modal dan Pelayanan Terpadu Satu Pintu (DPMPTSP) Kota Magelang}

Dinas Penanaman Modal dan Pelayanan Terpadu Satu Pintu merupakan organisasi perangkat daerah yang mempunyai peran dan fungsi di bidang penyelenggaraan pelayanan perizinan maaupun non perizinan. Penyelenggaraan Pelayanan Terpadu Satu Pintu (PPTSP) di Kota Magelang berawal dengan dibentuknya Unit Pelayanan Tekhnis Daerah (UPTD) Pelayanan Satu Atap (PSA) yang merupakan bagian dari Dinas Pendapatan Daerah Kota Magelang sebagai cikal bakalnya. Dengan terbitnya Peraturan Menteri Dalam Negeri Nomor 24 Tahun 2006 tentang Pedoman Penyelenggaraan Pelayanan Terpadu Satu Pintu maka Pemerintah Kota Magelang telah membentuk Dinas Pelayanan Terpadu Dan Penanaman Modal (DPMPTM) berdasarkan Peraturan Daerah Kota Magelang Nomor 1 Tahun 2007 tentang Perubahan atas Peraturan Daerah Nomor 5 tahun 2003 tentang Susunan Organisasi dan Tata Kerja Dinas Daerah.

\section{B. Proses Penyusunan SPJ Pengeluaran di DPMPTSP Kota Magelang}

Setiap belanja Satuan Kerja Perangkat Daerah (SKPD) tentunya sangat berkaitan dengan lembaga pemerintahan. Belanja SKPD merupakan semua pengeluaran yang gunanya untuk membiayai kegiatan operasional kantor seharihari. Dalam rangka pengeluaran kas yang digunakan untuk belanja operasional kantor, bendahara pengeluaran menggunakan uang berupa kas yang berada di tangan. Aktivitas pengeluaran kas mencakup semua pengeluaran kas dari bendahara pengeluaran, baik untuk pembayaran belanja yang sudah definitif, pembayaran yang bersifat uang muka, maupun pengeluaran kas dalam rangka penyetoran pajak. Belanja yang sudah definitif adalah belanja yang sudah diserahterimakan barang atau jasanya, seperti pembayaran pengadaan ATK yang sudah diserahterimakan, pembayaran perjalanan dinas yang sudah dilaksanakan, dan pembayaran uang makan minum pegawai. Sedangkan pembayaran yang bersifat uang muka adalah pembayaran yang dilakukan diawal sebelum barang atau jasa diterima. Aktivitas pengeluaran kas dari bendahara pengeluaran wajib dilengkapi dengan dokumen, bukti-bukti yang lengkap dan sah karena akan digunakan untuk penyusunan Surat Pertanggungjawaban (SPJ).

Surat Pertanggungjawaban (SPJ) Pengeluaran DPMPTSP Kota Magelang merupakan SPJ yang disusun oleh Bendahara Pengeluaran secara administratif, sebagai pertanggungjawaban penggunaan uang. Selain itu, SPJ ini juga merupakan penggabungan dari pertanggungjawaban (SPJ) Pengeluaran Pembantu pada masing-masing bidang. Bendahara pengeluaran pembantu akan menyusun SPJ Pengeluaran sebagai bentuk pertanggungjawaban atas penggunaan dana UP, GU, dan TU berdasarkan bukti-bukti pengeluaran yang ada. Bendahara pengeluaran pembantu mencatat pengeluaran atas penggunaan tersebut di buku kas pengeluaran pembantu, buku pajak PPN/PPh pembantu, dan buku panjar pembantu. 
Selanjutnya SPJ yang telah selesai disusun oleh bendahara pengeluaran pembantu, akan diserahkan ke bendahara pengeluaran untuk diteliti kelengkapan dokumennya. Dalam hal ini bendahara pengeluaran juga menyusun SPJ pengeluaran dengan menyiapkan beberapa dokumen yaitu buku kas umum pengeluaran, buku pembantu pengeluaran per rinci obyek, buku pembantu kas tunai, buku pembantu simpanan/bank, buku pembantu panjar, buku pembantu pajak, dan SPJ pengeluaran pembantu yang sudah disusun oleh bendahara pengeluaran pembantu. Selanjutnya, SPJ pengeluaran tersebut diverifikasi oleh pihak verifikator dan PPK-OPD. SPJ yang sudah diteliti dan dinyatakan lengkap, kemudian diserahkan kepada kepala dinas untuk disahkan, dan selanjutnya diarsipkan

\section{Faktor Yang Menghambat Penyusunan SPJ Pengeluaran}

\section{Pembagian Kerja}

Berdasarkan hasil pengamatan yang dilakukan di DPMPTSP Kota Magelang, penulis mengamati masalah yang terdapat di DPMPTSP Kota Magelang dalam penyusunan SPJ Pengeluaran. Masalah yang timbul dalam penyusunan SPJ ini disebabkan karena semua pegawai merangkap jabatan. Hal ini mengakibatkan pegawai melakukan tugas pokok ataupun fungsi yang lebih dari seharusnya. Sehingga pegawai yang ada di DPMPTSP Kota Magelang mendapatkan banyak tugas di lain fungsi.

Menurut hasil wawancara yang dilakukan penulis kepada bendahara pengeluaran pembantu DPMPTSP Kota Magelang, tugas pokok dan fungsi dari Bendahara pengeluaran pembantu tidak hanya melakukan tugasnya dalam penyusunan belanja pengeluaran saja tetapi juga melakukan tugas sebagai analis perizinan. Banyaknya tugas yang diterima oleh masing-masing pegawai, bisa menyebabkan kinerja pegawai tersebut tidak maksimal. Hal tersebut dikarenakan pegawai tidak bisa mengerjakan dua hal pekerjaan yang berbeda pada waktu yang sama. Kinerja pegawai merupakan penyelesaian pekerjaan secara tepat waktu dengan menghasilkan pekerjaan yang berkualitas sesuai target yang ditentukan. Dengan demikian diperlukan pembagian kerja yang tepat, dan evaluasi kinerja pegawai agar memberikan hasil kinerja yang optimal dalam organisasi tersebut.

\section{Dokumen Pelengkap SPJ}

Surat Pertanggungjawaban (SPJ) Pengeluaran merupakan suatu bentuk pertanggungjawaban atas penggunaan dana yang telah digunakan untuk kegiatan operasional kantor sehari-hari. SPJ yang disusun oleh Bendahara Pengeluaran secara administratif dan fungsional berisi saldo kas yang telah direkapitulasi.

Dalam proses penyusunan SPJ pengeluaran, bendahara pengeluaran membutuhkan bukti-bukti transaksi yang berupa nota, kuitansi, dan bukti transaksi lainnya. Bukti tersebut menjelaskan dana-dana yang dikelola oleh bendahara pengeluaran yang telah digunakan untuk belanja operasional kantor. Selain itu, bendahara pengeluaran juga membutuhkan dokumen pelengkap lainnya seperti undangan kegiatan atau rapat, laporan kegiatan, notulensi, daftar hadir, nota dinas dan lain-lain. Banyaknya dokumen pelengkap yang dibutuhkan seringkali menghambat proses penyusunan SPJ yang dilakukan oleh 
bendahara pengeluaran pembantu DPMPTSP Kota Magelang. Hal itu dikarenakan dokumen-dokumen tersebut harus ditandatangani oleh atasan dan diperlukan waktu menunggu sangat lama.

\section{KESIMPULAN}

Berdasarkan hasil penelitian dan pembahasan maka dapat diambil kesimpulan bahwa Dinas Penanaman Modal dan Pelayanan Terpadu Satu Pintu (DPMPTSP) Kota Magelang dalam melakukan penyusunan Surat Pertanggungjawaban (SPJ) Pengeluaran sudah melaksanakan penyusunan SPJ dengan baik dan tepat waktu, karena dalam pelaporan SPJ tidak pernah mengalami keterlambatan. Masalah masalah yang dihadapi oleh bendahara pengeluaran DPMPTSP Kota Magelang dalam penyusunan surat pertanggungjawaban (SPJ) pengeluaran dikarenakan semua pegawai merangkap jabatan, sehingga kinerja pegawai tersebut tidak maksimal dikarenakan banyaknya tugas yang diterima oleh pegawai. Selain itu, banyaknya dokumen pelengkap yang diperlukan dalam penyusunan SPJ Pengeluaran juga menghambat penyusunan SPJ Pengeluaran.

\section{UCAPAN TERIMA KASIH}

Dalam penyusunan artikel ini, penulis berterima kasih kepada : (1) Allah SWT yang telah melimpahkan rahmat dan hidayah-Nya kepada kita sehingga dapat menyelesaikan penyusunan artikel ini, (2) Pegawai DPMPTSP Kota Magelang, yang telah memberikan informasi yang dibutuhkan dalam penyusunan artikel ini, (3) Keluarga dan teman-teman semua yang telah mendukung menyelesaikan artikel ini.

\section{DAFTAR PUSTAKA}

Bastian, I. (2007). Sistem Akuntansi Sektor Publik. Jakarta: Salemba Empat.

Fitriani, R. (2018). Pengaruh Kualitas Sumber Daya Manusia, Pemanfaatan Teknologi Informasi, dan Pengendalian Intern Akuntansi terhadap Ketepatan Waktu (Timeliness) Laporan Pertanggungjawaban Belanja Perjalanan Dinas. Universitas Tanjungpura, 1-12.

Halim, A. (2002). Akuntansi Sektor Publik : Akuntansi Keuangan Daerah. Jakarta: Salemba Empat.

Halim, A., \& Kusufi, M. S. (2007). Akuntansi Sektor Publik. Jakarta: Salemba Empat.

Hasibuan, M. S. P. (2007). Manajemen Sumber Daya Manusia. Jakarta: PT Bumi Aksara.

Indriantoro, N., \& Supomo, B. (2002). Metodologi Penelitian Bisnis Untuk Akuntansi dan Manajemen. Yogyakarta: BPFE.

LAN, \& BPKP. (2000). Akuntabilitas dan Good Governance. Jakarta: Lembaga Administrasi Negara. 
Maniagasi, H. A., Bharanti, E., \& Christian, F. (2016). Faktor-Faktor Yang Menyebabkan Keterlambatan Penyusunan Anggaran Pendapatan Belanja Daerah (Studi Pada Pemerintah Daerah Kabupaten Sarmi Tahun Anggaran 2010-2012). Jurnal Kajian Ekonomi \& Keuangan Daerah, 113-115.

Mardiasmo. (2009). Akuntansi Sektor Publik. Yogyakarta: Andi.

Rahmatiah, D. R. (2016). Analisis Penatausahaan Dan Penyusunan Laporan Pertanggungjawaban. Jurnal EMBA : Jurnal Riset Ekonomi, Manajemen, Bisnis, dan Akuntansi, 743-752.

Republik Indonesia. Peraturan Menteri Dalam Negeri Nomor 13 Tahun 2006 tentang Pedoman Pengelolaan Keuangan Daerah, Jakarta

Peraturan Menteri Dalam Negeri Nomor 21 Tahun 2011 sebagai revisi Permendagri 13/2006 tentang Pedoman Pengelolaan Keuangan Daerah, Jakarta

Siregar, B. (2015). Akuntansi Sektor Publik. Yogyakarta: UPP STIM YKPN.

The, F. Z., Tinangon, J. J., \& Elim, I. (2016). Analisis Penatausahaan dan Penyusunan Laporan Pertanggungjawaban Bendahara Serta Penyampaiannya Pada Dinas Pendapatan Pengelola Keuangan dan Aset Daerah Kota Manado. Jurnal Berkala Ilmiah Efisiensi, 604-611. 